\title{
Self Disclosure Santri Remaja di Media Sosial: Peran Self Identity Status dan Affiliation Motive
}

\author{
Fenti Hikmawati, Alida Nurawaliah, Ila Nurlaila Hidayat \\ Fakultas Psikologi, Univesitas Islam Negeri Sunan Gunung Djati Bandung, Indonesia \\ e-mail: fenti.hikmawati@uinsgd.ac.id
}

\begin{abstract}
One of the most important developmental tasks for adolescents is to find self-identity. Some of the teenagers take education in Islamic boarding schools so that they have a special predicate as Islamic students or santri. For this reason, it is important to understand how the process of developing adolescent students in the formation of their identity status as Islamic students in the current modern era. This study aims to determine the effect of self identity status and affiliation motive on self disclosure in adolescent Islamic students. This study uses a quantitative correlational method with a total of 140 students was obtained through random sampling techniques. Data collection tools using self identity status scale, affiliation motive scale and self disclosure scale. The multiple linear regression analysis show that there is an influence of self identity status and affiliation motive on self disclosure on social media.
\end{abstract}

Keywords: self identity status, affiliation motive, self disclosure, adolescent Islamic student

\begin{abstract}
Abstrak
Salah satu tugas perkembangan remaja yang sangat penting yaitu mencari identitas diri. Sebagian dari remaja menempuh jenjang pendidikan di pesantren sehingga menyandang predikat khusus sebagai santri. Untuk itu penting dipahami bagaimana proses perkembangan santri remaja dalam pembentukan status identitas dirinya sebagai santri di era modern saat ini. Penelitian ini bertujuan untuk mengetahui peran self identity status dan affiliation motive terhadap self disclosure pada santri remaja. Penelitian ini menggunakan metode kuantitatif korelasional yang bersifat kausalitas, dengan subjek sejumlah 140 santri, diperoleh melalui teknik random sampling. Alat ukur menggunakan skala self identity status, skala affiliation motive dan skala self disclosure. Hasil penelitian menggunakan analisis regresi linier berganda menunjukkan terdapat pengaruh self identity status dan affiliation motive terhadap self disclosure di media sosial pada santri remaja.
\end{abstract}

Kata Kunci: self identity status, motif afiliasi, pengungkapan diri, santri remaja

\section{Pendahuluan}

Masa remaja sering dikaitkan dengan peningkatan pengambilan risiko, kebutuhan akan koneksi sosial dan penerimaan teman sebaya, serta meningkatnya kepekaan terhadap pengaruh teman sebaya (Andrews dkk., 2020). Pengaruh sosial teman sebaya juga terlihat secara online (Nesi dkk., 2018). Misalnya, remaja (berusia 14-17 tahun) lebih cenderung melakukan posting konten seksual secara online jika teman sebayanya melakukan hal demikian. Tingkat pengaruh teman sebaya dimungkinkan akan lebih kuat secara online karena luasnya jangkauan media sosial serta sifatnya yang selalu bergerak cepat. Remaja mengungkapkan lebih banyak data pribadi dan menerapkan pengaturan privasi yang lebih longgar pada situs jejaring sosial dibandingkan dengan orang dewasa (Walrave dkk., 2012).

Agar menarik perhatian serta dikenal di kalangan sesama pengguna jejaring sosial biasanya para remaja cenderung melakukan pengungkapan diri (Selfdisclosure), yang didefinisikan sebagai suatu jenis komunikasi dimana kita mengungkapkan informasi tentang diri kita sendiri yang biasanya kita sembunyikan (Devito, 2011). Aspek pengungkapan diri 
dibagi menjadi lima dimensi, yaitu: 1) kedalaman atau keintiman (depth or intimacy); 2) ketepatan atau kejujuran (accuracy or honesty); 3) kuantitas (amounth); 4) valensi (valence); serta 5) tujuan (intention).

Menurut remaja, media sosial membantu mereka untuk berkoneksi dengan jaringan sosial yang luas sehingga menjadikan diri mereka dikenal orang lain yang memungkinkan terjadinya sebuah hubungan (Christofides dkk., 2009). Hal ini meningkatkan peluang bagi remaja menggunakan situs pertemanan sosial tersebut untuk memaparkan informasi mengenai dirinya.

Berdasarkan data wawancara dan observasi pada salah satu pesantren yang berada di kabupaten Garut Jawa Barat, diketahui santri cenderung lebih suka berinteraksi dan lebih terbuka saat menggunakan jejaring sosial. Contohnya salah satu santri lebih antusias dan lebih meningkat minatnya untuk melakukan interaksi, dan santri cenderung mengungkapkan apa yang terjadi pada dirinya baik positif maupun negatif di media sosial dan mereka tidak mempertimbangkan apa yang terjadi di depan. Banyak santri yang menampilkan status berpacaran di media sosial sedangkan hal itu tidak mencerminkan status dia sebagai santri. Mereka pun lebih mencari kualitas pertemanan melalui media sosial tersebut, sehingga mereka lebih senang dan aktif di media sosial.

Kenyataan yang terjadi pada santri tersebut, menunjukkan adanya ketidaksesuaian dengan beberapa sifat atau nilai yang dikenal oleh masyarakat, sebagai sesuatu yang melekat pada predikat santri tersebut. Ghofur (2007, dalam Mar'ati, 2014) menyatakan terdapat sejumlah nilai atau tradisi santri yang berperan membentuk kepribadian mereka yaitu: sikap hormat dan ta'dzim (respect), persaudaraan (caring dan compassion), keikhlasan dan kesederhanaan (knowing), nilai kemandirian (responsibility), larangan melanggar aturan (honesty dan fairness), nilai keteladanan (modelling dan habituation). Sejalan dengan hal itu, ditemukan terdapat lima karakter yang dominan dimiliki santri yaitu bersyukur, kebaikan hati, kewarganegaraan, keadilan, dan harapan. Sedangkan karakter yang lemah terdapat pada regulasi diri, keberanian, kreativitas, serta perspektif dan rasa humor (Nashori, 2016).

Fenomena yang terjadi pada santri, mereka cenderung lebih terbuka di media sosial tanpa mempertimbangkan konten statusnya. Seharusnya sebagai santri dapat memilih mana yang layak di update serta mana yang tidak. Terkait hal-hal yang mendorong seringnya melakukan update status, para santri menjelaskan bahwa mereka cenderung lebih nyaman, lebih terbuka dengan dunia yang luas, lebih banyak teman, memiliki eksistensi, dapat mengekspos kegiatan sehingga banyak dikenal, menambah pertemanan dengan santri pesantren lain, serta berkomunikasi menjadi lebih mudah. Apabila dikaitkan dengan identitas diri mereka sebagai santri yang berbeda dengan siswa pada umumnya, hasil wawancara menunjukkan bahwa ketika melalukan update status, terdapat batasan tersendiri bagi mereka karena sebagai santri harus menjaga nama baik pesantren yang memberi aturan bahwa di media sosial tidak boleh melakukan update secara sembarangan. Sebagai contoh kasus mengenai update foto bersama pacar hal itu tidak mencerminkan identitas seorang santri karena mereka mengetahui bahwa sebagai santri seharusnya bisa menunjukkan keteladanan dan memberikan manfaat bagi orang lain. Selain itu, mereka mengetahui bahwa media sosial yang saat ini banyak digunakan, bagi santri seharusnya menjadi media berdakwah dan silaturahmi dengan santri pesantren lain.

Penggunaan jejaring sosial semakin diminati para remaja untuk pemenuhan kebutuhan afiliasi. Sebagaimana fenomena pada santri menunjukkan kecenderungan serupa yaitu adanya motif afiliasi yang 
merupakan kebutuhan untuk meningkatkan kualitas pertemanan dengan santri pesantren lain yang mendasari keterbukaan diri mereka pada media sosial.

Kebutuhan afiliasi merupakan kebutuhan akan kehangatan dan sokongan dalam hubungannya dengan orang lain (Hill, 1987). Kebutuhan afiliasi adalah kecenderungan untuk membentuk pertemanan dan bersosialisasi, untuk berinteraksi secara dekat dengan orang lain, untuk bekerja sama dan berkomunikasi dengan orang lain dengan cara bersahabat, dan untuk jatuh cinta. Selain itu kebutuhan afiliasi merupakan kebutuhan dasar untuk mencari dan mempertahankan relasi interpersonal. Kebutuhan ini dapat dilihat melalui empat aspek (Hill, 1987), yaitu: positive stimulation, berupa rangsangan afeksi dan kognisi menyenangkan yang diperoleh dari tindakan afiliasi; emotional support, berupa dukungan atau masukan yang dapat meredakan tekanan; social comparison, merupakan suatu proses mencapai evaluasi diri (keterampilan, bakat, sikap, dan nilai) dengan membandingkan diri sendiri dengan orang lain yang secara umum mirip dengan dirinya hingga diperoleh penilaian terhadap diri sendiri; serta attention, berupa potensi untuk meningkatkan harga diri dan citra diri melalui pujian dan pemusatan perhatian orang lain pada diri seseorang.

Kebutuhan afiliasi mendorong seseorang menjalin dan mempertahankan suatu hubungan dengan orang lain. Walaupun kebutuhan afiliasi dimiliki setiap manusia, namun terdapat perbedaan ditinjau dari besar dorongannya antara individu yang satu dengan individu lain.

Individu yang menunjukkan keterbukaan diri bisa jadi mereka adalah orang yang memiliki kebutuhan afiliasi yang lebih tinggi dibanding dengan yang lainnya. Beberapa penelitian menunjukkan hubungan kebutuhan afiliasi, keterbukaan diri, serta intensitas penggunaan jejaring sosial secara umum maupun khusus pengguna facebook, baik pada remaja maupun dewasa awal (Rinjani \& Firmanto, 2013; Laila, 2014; Minanti, 2016). Penelitian lain menegaskan pula peran signifikan dari tipe kepribadian extraversion dan neuroticism terhadap keterbukaan diri (Fauzia dkk., 2019). Sementara itu privasi ditemukan berhubungan negatif dengan keterbukaan diri (Lee \& Andriani, 2012). Adapun intimate friendship dengan self disclosure pada mahasiswa ditemukan hasil berbeda antara pengguna WhatsApp yang terbukti berhubungan positif (Rizal \& Rizal, 2021), sedangkan pada pengguna facebook terbukti hubungannya negatif (Pohan \& Dalimunthe, 2017).

Terdapat sejumlah faktor yang memengaruhi self disclosure (Devito, dalam Masturah, 2013) yaitu: 1) besar kelompok, yang mana pengungkapan diri lebih banyak terjadi dalam kelompok kecil dibandingkan besar; dan 2) perasaan menyukai (afiliasi), kita membuka diri dengan orang-orang yang kita sukai atau cintai; 3) efek diadik, individu melakukan keterbukaan diri apabila orang lain juga melakukan keterbukaan diri; 4) kompetensi, orang yang kompeten lebih banyak melakukan keterbukaan diri daripada yang tidak kompeten; 5) kepribadian, orang yang memiliki kepribadian pandai bergaul atau ekstrovert cenderung lebih terbuka dibandingkan orang yang kurang pandai bergaul atau introvert. 6) topik, seseorang lebih cenderung membuka diri tentang topik tertentu dari pada topik yang lain, ataupun informasi yang bersifat positif daripada negatif; dan 7) jenis kelamin, pada umumnya wanita lebih suka terbuka dari laki-laki. Berdasarkan faktor-faktor tersebut, salah satunya adalah perasaan menyukai atau afiliasi. Hal ini sebagaimana dapat diamati dari para santri remaja bahwa diantara yang mendasari mereka lebih terbuka di media sosial adalah perasaan menyukai serta keinginan untuk terhubung dengan orang lain sehingga santri tersebut lebih sering melakukan update status. 
Menurut Erikson (dalam Marcia, 1993) remaja merupakan salah satu tahapan hidup yang sangat penting untuk pembentukan identitas. Pada tahapan tersebut, remaja menghadapi tugas utama mencari dan menegaskan eksistensi dan jati dirinya, mengetahui kekuatan dan kelemahan diri sendiri, mencari arah dan tujuan, menjalin hubungan dengan orang yang dianggap penting. Meyakinkan diri sendiri dan orang lain, bahwa dirinya telah mampu menyelesaikan tugas-tugas perkembangan secara efektif mempersiapkan diri menjelang masa dewasanya. Hal ini terjadi sebagai pembentukan status identitas diri remaja. Identitas merupakan sesuatu yang melekat pada diri seseorang yang membedakan antara satu orang dengan yang lain. Erikson (dalam Marcia, 1933) menyatakan bahwa identitas adalah suatu gagasan yang dimiliki seseorang mengenai bagaimana ia mendefinisikan tentang dirinya.

Status identitas diri adalah identitas diri didasarkan pada hasil proses eksplorasi dan komitmen menurut teori Marcia. Status identitas terbentuk dari kombinasi secara interaksi antara eksplorasi dan komitmen. Tingkat ketajaman, kekuatan, dan keluasan masing-masing akan menentukan status identitas yang akan dicapai seseorang, termasuk remaja. Status identitas yang dibangun dari hasil eksplorasi dan komitmen yang dicapai seorang remaja, meliputi: achievement (eksplorasi dan komitmen tinggi), foreclosure (eksplorasi rendah, komitmen tinggi), moratorium (eksplorasi tinggi, komitmen rendah), dan diffusion (eksplorasi dan komitmen samasama rendah). Status identitas diri yang dapat dikenali dari remaja yang memiliki peran sebagai santri, dimungkinkan berbeda dengan status identitas diri remaja pada umumnya, sehingga dimungkinkan mendasari keterbukaan diri di media sosial secara berbeda pula. Akan tetapi temuan awal menunjukkan aspek komitmen yang cenderung rendah pada status identitas diri sebagai santri sehingga tampak tidak jauh berbeda konten status mereka sebagai santri dengan remaja pada umumnya.

Berdasarkan fenomena bahwa santri remaja di pesantren cenderung memenuhi kebutuhan afiliasi dan status dirinya sebagai santri dengan bersikap lebih terbuka di media sosial. Demikian halnya, sejauh ini penelitian yang ada lebih menekankan pada kaitan antara motif afiliasi, keterbukaan diri serta intensitas penggunaan jejaring sosial baik secara umum maupun spesifik pada jenis jejaring sosial tertentu. Maka penelitian ini mencoba menggali hal serupa dengan menambahkan hal baru terkait status identitas diri yang melekat pada kalangan tertentu dari remaja yaitu mereka yang memiliki status sebagai santri. Dengan demikian penelitian ini bertujuan mengetahui peran self identity status dan affiliation motive terhadap self disclosure pada santri remaja.

\section{Metode Penelitian}

Penelitian ini menggunakan metode kuantitatif korelasional. Dilakukan terhadap sampel penelitian sebanyak 140 santri dari total populasi sasaran sejumlah 280 santri Pesantren Persatuan Islam 87 Pangatikan Garut Jawa Barat. Subjek merupakan santri remaja berusia 15-16 tahun, yang memiliki media sosial. Pengambilan sampel menggunakan teknik random sampling.

Instrumen penelitian berjenis skala Likert yang disusun peneliti. Terdapat 3 skala yang digunakan yaitu skala self identity status, affiliation motive dan self disclosure. Skala Self Identity Status disusun berdasarkan dua aspek yang dikemukakan Marcia (1993). Skala ini terdiri dari 29 item. Nilai validitas sebesar .880 (aspek eksplorasi) dengan contoh item "Saya meyakini bahwa saya sebagai santri harus aktif dalam kegiatan keagamaan di lingkungan sekitar", serta .889 (aspek komitmen) dengan contoh item "Saya turut berperan di media sosial karena seorang santri memiliki kewajiban menyampaikan 
pesan dakwah kapan pun dan dimana pun". Adapun nilai reliabilitas alat ukur sebesar .808 .

Skala Affiliation Motive disusun berdasarkan empat aspek menurut Hill (1987) yaitu: emotional support, attention, positive stimulation, dan social comparison. Skala ini terdiri dari 22 item. Nilai validitas berkisar antara .666 - .859, sedangkan nilai reliabilitas sebesar .852 .

Skala self disclosure disusun berdasarkan lima aspek menurut Devito (2011) yaitu: kedalaman atau keintiman (depth or intimacy), ketepatan atau kejujuran (accuracy or honesty), kuantitas (amounth), valensi (valence), serta tujuan (intention). Skala ini terdiri dari 26 item. Contoh item "Ketika saya membuka diri, saya sepenuhnya menyadari apa yang saya ungkapkan" dan "Ketika saya memulai mengungkapkan diri, maka pengungkapan diri saya dapat berlangsung lama". Nilai validitas berkisar antara .492 - .868, sedangkan nilai reliabilitas sebesar .796 .

\section{Hasil Penelitian dan Pembahasan}

\section{Analisis Deskriptif}

Analisis deskriptif memberikan gambaran mengenai tinggi rendahnya self identity status (Mean 92.05), affiliation motive (Mean 64.87), dan self disclosure (Mean 71.52) yang dimiliki subjek, dengan kategorisasi berdasarkan nilai mean.

Tabel 1

Kategorisasi Self Identity Status, Affiliation Motive dan Self Disclosure

\begin{tabular}{lcc}
\hline \multicolumn{1}{c}{ Kategori } & Jumlah & Persentase \\
\hline Self Identity Status & & \\
Tinggi & 71 & $50.7 \%$ \\
Rendah & 69 & $49.3 \%$ \\
Affiliation Motive & & \\
Tinggi & 75 & $53.6 \%$ \\
Rendah & 65 & $46.4 \%$ \\
Self Disclosure & & \\
Tinggi & 61 & $43.6 \%$ \\
Rendah & 79 & $56.4 \%$ \\
\hline
\end{tabular}

Tabel 2

Kategorisasi Jenis Self Identity Status

\begin{tabular}{lccc}
\hline & & \multicolumn{2}{c}{ Commitment } \\
\cline { 3 - 4 } & & Tinggi & Rendah \\
\hline Exploration & Tinggi & Achivement & Moratorium \\
& & $48(34.3 \%)$ & $19(13.6 \%)$ \\
& Rendah & Foreclosure & Diffusion \\
& & $28(20 \%)$ & $45(32.1 \%)$ \\
\hline
\end{tabular}

Berdasarkan tabel 1 dapat diketahui bahwa pada self identity status serta affiliation motive, santri yang memeroleh skor tinggi relatif lebih banyak yaitu sebesar $50.7 \%$ dan $53.6 \%$. Sebaliknya pada self disclosure lebih banyak yang memperoleh skor rendah yaitu sebesar $56.4 \%$.

Secara khusus pada variabel self identity status, mengingat tinggi rendahnya skor individu pada aspek eksplorasi dan komitmen akan menunjukkan status identitas dirinya tergolong kepada salah satu dari empat jenis self identity status (Marcia, 1993), pada tabel 2 disajikan gambaran mengenai hasil perbandingan tersebut.

Tabel 2 menunjukkan bahwa secara berturut-turut persentase terbesar sampai dengan terkecil terdapat pada jenis achievement (eksplorasi dan komitmen tinggi), diffusion (eksplorasi dan komitmen rendah), foreclosure (eksplorasi rendah, komitmen tinggi) dan moratorium (eksplorasi tinggi, komitmen rendah).

\section{Analisis Inferensial}

Hasil uji asumsi klasik menunjukkan bahwa data berdistribusi normal berdasarkan uji normalitas terhadap nilai residual menggunakan Kolmogorov Smirnov (Sig. .279 > .05); tidak terdapat multikolinearitas berdasarkan nilai VIF $1.064(\leq 10)$ dan nilai tolerance .940 ( $>$ .10); serta tidak terdapat heteroskedastisitas berdasarkan metode Glejser (Sig. .177 dan $.146>$.05) (Ghozali, 2011).

Berdasarkan hasil perhitungan analisis regresi linier berganda, diperoleh beberapa hasil. Hasil uji parsial pada tabel 3 
Tabel 3

Hasil Uji $t$

\begin{tabular}{lcl}
\hline Variabel & $\mathrm{T}$ & Sig. \\
\hline Self Identity Status & 2.253 & .026 \\
Affiliation Motive & 3.172 & .002 \\
\hline
\end{tabular}

Tabel 4

Hasil Uji Signifikansi Simultan (Uji F)

\begin{tabular}{lccccc}
\hline Model & Sum of Squares & Df & Mean Square & $F$ & Sig. \\
\hline Regression & 983.865 & 2 & 491.932 & 9.918 & $.000^{b}$ \\
Residual & 6795.071 & 137 & 49.599 & & \\
Total & 7778.936 & 139 & & & \\
\hline
\end{tabular}

a. Dependent Variable: Self Disclosure

b. Predictors: (Constant), Affiliation Motive, Self Identity Status

Tabel 5

Hasil Uji Regresi (Koefisien Determinasi)

\begin{tabular}{ccccc}
\hline Model & $R$ & $R$ Square & Adjusted $R$ Square & Std. Error of the Estimate \\
\hline 1 & $.356 \mathrm{a}$ & .126 & .114 & 7.04266 \\
\hline
\end{tabular}

a. Predictors: (Constant), Affiliation Motive, Self Identity Status

Tabel 6

Hasil Uji Regresi (Koefisien Regresi)

\begin{tabular}{|c|c|c|c|c|c|}
\hline \multirow{2}{*}{ Model } & \multicolumn{2}{|c|}{ Unstandardized Coefficients } & Standardized Coefficients & \multirow[b]{2}{*}{$T$} & \multirow{2}{*}{ Sig. } \\
\hline & $B$ & Std. Error & Beta & & \\
\hline (Constant) & 40.395 & 7.539 & & 5.358 & .000 \\
\hline 1 Self Identity Status & .174 & .077 & .186 & 2.253 & .026 \\
\hline Affiliation Motive & .234 & .074 & .261 & 3.172 & .002 \\
\hline
\end{tabular}

a. Dependent Variable: Self Disclosure

menunjukkan nilai signifikansi sebesar .026 $(<.05)$ pada variabel self identity status dan .002 (< .05) pada variabel affiliation motive. Hal tersebut menunjukkan bahwa secara terpisah, baik self identity status maupun affiliation motive berpengaruh terhadap self disclosure santri remaja.

Hasil uji simultan pada tabel 4 menunjukkan nilai signifikansi sebesar $.000(<.05)$ yang berarti secara bersamasama self identity status dan affiliation motive berpengaruh terhadap self disclosure santri remaja. Tabel 5 menunjukkan besarnya nilai koefisien determinasi dari self identity status dan affiliation motive terhadap self disclosure santri remaja yaitu sebesar $12.6 \%$.

Adapun pada tabel 6 dapat diketahui persamaan regresi $(\mathrm{Y}=40.395+.174 \mathrm{X} 1+$ .234 X2). Nilai konstanta pada dependent variable menunjukkan bahwa jika self identity status (X1) dan affiliation motive (X2) bernilai nol, maka besarnya rata-rata self disclosure (Y) akan bernilai 40.395. koefisien regresi yang bernilai positif pada kedua independent variable, menunjukkan bahwa setiap pertambahan self identity status (X1) sebesar satu satuan akan menyebabkan meningkatnya self disclosure (Y) sebesar .174. Demikian pula setiap pertambahan affiliation motive (X2) sebesar satu satuan akan menyebabkan meningkatnya self disclosure (Y) sebesar .234 .

\section{Pembahasan}

Hasil kategorisasi menunjukkan bahwa santri lebih banyak yang memiliki self disclosure rendah, dimungkinkan karena keterbukaan diri terhadap orang lain, khususnya teman sebaya, lebih banyak terjadi dalam komunikasi tatap muka secara langsung, terlebih bagi santri yang tinggal di asrama. Sebagaimana penelitian Knop dkk. (2016) bahwa waktu offline merupakan waktu yang berkualitas untuk 
pengungkapan diri dalam kelompok. Terkait dengan aspek pengungkapan diri (jumlah, kedalaman, keluasan, valensi), terbukti lebih banyak jumlah, lebih luas dan lebih mendalam untuk pengungkapan diri dalam kelompok secara offline, tetapi kurang bervalensi positif daripada pengungkapan diri dalam kelompok secara online.

Self disclosure yang mayoritas cenderung rendah pada santri remaja ini, belum dapat dipastikan apakah hal ini menunjukkan kondisi umum pada santri memang demikian ataukah tidak, karena sejauh ini belum ditemukan penelitian yang membandingkan self disclosure pada santri serta non santri khususnya remaja. Penelitian terkait yang ditemukan diantaranya membandingkan self disclosure remaja pada dua etnis berbeda yaitu remaja Madura memiliki tingkat pengungkapan diri yang lebih tinggi dibandingkan dengan remaja Jawa (Masturah, 2013), serta pengungkapan diri pada remaja lebih tinggi dibandingkan dewasa (Walrave dkk., 2012). Selain itu ada pula penelitian yang membandingkan self disclosure berdasarkan jenis kelamin. Ditemukan tidak adanya perbedaan gender dalam hal keluasan pengungkapan diri. Namun wanita cenderung mengungkapkan diri lebih dalam daripada pria. Baik pria maupun wanita cenderung mengungkapkan diri lebih banyak kepada wanita daripada pria (Paluckaitè \& Žardeckaitè-Matulaitienè, 2012).

Meskipun kategorisasi menunjukkan mayoritas santri remaja memiliki self disclosure yang rendah, namun tidak dapat dipungkiri bahwa ada sebagian dari mereka yang memiliki self disclosure tinggi. Hal ini merupakan bagian yang tidak terelakkan dari kemajuan teknologi khususnya situs jejaring sosial. Pada santri remaja yang memiliki self disclosure tinggi akan terlihat bahwa mereka tidak hanya mengungkapkan diri secara verbal melainkan secara nonverbal. Sebagaimana penelitian Kim dan Dindia (2011) yang memperluas definisi pengungkapan diri online dari definisi tradisional yaitu pengungkapan diri secara verbal. Dalam hal ini Kim dan Dindia menambahkan bahwa gambar diri dan tautan favorit yang diposting di web merupakan bagian dari cara seseorang mengungkapkan informasi tentang diri mereka sendiri.

Tinggi rendahnya pengungkapan diri seseorang, ternyata dipengaruhi pula oleh tipe perangkat yang digunakan. Individu cenderung lebih membuka diri, termasuk posting media sosial, saat membuat konten pada smartphone mereka dibandingkan dengan komputer pribadi. Kecenderungan ini berkaitan dengan dua efek psikologis yang dirasakan berbeda akibat perbedaan sifat pada kedua perangkat tersebut. Pertama, adanya perasaan nyaman yang terasosiasi dengan smartphone, dan kedua, adanya kecenderungan memusatkan atensi secara sempit pada tugas pengungkapan di tangan karena ukuran perangkat yang lebih kecil (Melumad \& Meyer, 2020). Apabila meninjau kaitan hal ini pada santri, bahwa mereka ada yang tinggal di asrama ataupun di rumah, tentu penggunaan jenis perangkat mereka dapat berbeda. Hal tersebut berkaitan dengan adanya aturan pesantren yang lebih tegas membatasi santri untuk membawa ataupun menggunakan perangkat smartphone ke pesantren khususnya asrama. Dengan demikian hal ini dimungkinkan pula berkaitan dengan tinggi rendahnya self disclosure yang ditampilkan santri.

Remaja santri yang memiliki self identity status tinggi dapat diartikan bahwa mereka memiliki tingkat eksplorasi dan komitmen yang tinggi dimana seorang santri terus menggali dan mencari informasi serta pemahaman yang mendalam untuk pengetahuan bagi dirinya sehingga terus bisa berkembang di zaman modern yang lebih canggih dengan teknologi dan santri berkomitmen untuk terus menyebarluaskan ilmu pengetahuan agama di lingkungan masyarakat. Dalam kaitan dengan bentuk self identity status 
tersebut, nilai tinggi berarti mencerminkan identity achievement. Identitas ini merupakan bentuk status identitas pada individu yang berhasil menggali dan menguasai sejumlah informasi penting bagi dirinya, mampu membandingkan dengan rasa senang (sikap positif) berbagai segi positif atau negatif. Dengan demikian individu dengan segera mampu menentukan pilihan informasi mana yang diambil sebagai komponen pembentukan identitas dirinya. Di sisi lain, ketika menentukan pilihan atas alternatif, maka yang bersangkutan menunjukkan kesetiaan kuat terhadap pilihan itu, karena tahu bahwa pilihannya itu memang tepat bagi dirinya.

Sedangkan santri yang memiliki self identity status rendah berarti mereka lebih mengikuti apa yang sudah diberikan oleh pihak pesantren semata, tanpa menggali informasi lain dan hanya berkomitmen menjadi santri saat berada di lingkungan pesantren saja, kurang berupaya mengembangkan kepada masyarakat luas mengenai ilmu agamanya karena cenderung sibuk dengan urusan pribadi. Hal ini tercermin dari identity diffusion yang mana individu kurang memiliki semangat untuk menggali informasi yang diperlukan guna membentuk identitas dirinya, sehingga tidak membandingkan antara alternatif pilihan satu dengan yang lain, akhirnya mereka dapat mengalami kesulitan ketika harus membuat keputusan dengan cepat.

Pada santri remaja ditemukan pula yang menunjukkan identity foreclosure. Dalam hal ini eksplorasi yang dilakukan santri tidak maksimal karena kurang memanfaatkan kecanggihan teknologi. Pengetahuan tentang berbagai alternatif tindakan tidak dikuasai dengan baik, bahkan cenderung kurang senang mencari informasi. Pilihan-pilihan dibuat tanpa didukung pemahaman lengkap tentang kelebihan dan kelemahan secara obyektif dan proporsional. Akan tetapi setelah menentukan pilihan, santri remaja menunjukkan tingkat kesetiaan yang kuat dan tidak teralihkan oleh kemunculan alternatif baru yang boleh jadi lebih bersifat negatif.

Ada pula santri yang menunjukkan identity moratorium. Santri menampilkan hasil eksplorasi yang cukup baik, akan tetapi tidak didukung dengan tingkat komitmen yang seimbang. Dari segi komitmen, kurang menunjukkan keteguhan untuk mempertahankan alternatif yang telah menjadi pilihannya, mungkin karena yang bersangkutan kurang menguasai informasi tentang alternatif pilihannya tersebut. Sehingga tidak tahu tentang apa, bagaimana, serta kelebihan dari pilihan itu, sehingga cenderung mudah terombangambing oleh kemunculan alternatif baru yang berhasil ia eksplorasi.

Hasil penelitian ini menegaskan bahwa self identity status mempunyai pengaruh terhadap self disclosure di media sosial pada santri remaja artinya seorang yang beridentitas sebagai santri, dalam melakukan proses eksplorasi dan komitmen terhadap predikat santri tersebut, membuat mereka lebih terbuka mengenai dirinya di media sosial. Penelitian serupa pernah dilakukan terhadap siswa SMA yang menemukan bahwa pengungkapan diri di media sosial memiliki pengaruh terhadap status identity diffusion serta status identity foreclosure (Toyyebah, 2017). Dalam analisis deskriptifnya, pada penelitian tersebut pun menunjukkan hasil yang sama bahwa kedua jenis status identitas yang paling banyak dimiliki siswa adalah diffusion dan achievement. Hasil penelitian ini serta penelitian tersebut (Toyyebah, 2017) menunjukkan bahwa antara self identity status dengan self disclosure memiliki hubungan yang dapat bersifat timbal balik. Artinya proses eksplorasi dan komitmen dalam pencarian dan penegasan identitas diri dapat mendorong remaja untuk melakukan pengungkapan diri yang lebih tinggi, ataupun sebaliknya pengungkapan diri yang dilakukan dapat menentukan tingkat eksplorasi dan 
komitmen dalam menegaskan identitas dirinya.

Selanjutnya terkait temuan bahwa affliation motive mempunyai pengaruh terhadap self disclosure di media sosial pada santri remaja artinya seorang santri lebih terbuka menceritakan tentang dirinya di media sosial, hal itu didasari oleh adanya dorongan untuk memenuhi kebutuhan afiliasinya. Individu yang menunjukkan keterbukaan diri biasanya mereka adalah orang yang memiliki kebutuhan afiliasi yang lebih tinggi dibanding dengan yang lainnya. Sejalan dengan beberapa penelitian sebelumnya yang menunjukkan adanya hubungan signifikan kebutuhan afiliasi dengan pengungkapan diri dewasa awal pengguna media sosial (Minanti, 2016), kebutuhan afiliasi dengan intensitas akses facebook remaja (Rinjani \& Firmanto, 2013), kebutuhan afiliasi dan keterbukaan diri dengan intensitas penggunaan jejaring sosial (Ratnasari, 2015, Desiana, 2010; Laila, 2014). Penelitian lain menegaskan bahwa remaja pengguna facebook memiliki motif afiliasi terbesar untuk berteman dan mencari informasi guna memperluas jaringan pertemanan, sedangkan motif afiliasi terkecil untuk mendapatkan perhatian orang lain. Terdapat pula motifmotif afiliasi lain terkait intensitas hubungan yang lebih kuat seperti mempertahankan suatu hubungan, menunjukkan sikap bersahabat, memiliki keinginan baik, dan membina hubungan yang penuh kepercayaan (Pribadi, 2011).

Dalam Islam manusia hendaknya mengenal dan memahami siapa dirinya dan bagaimana perannya seperti dikemukakan dalam surah Luqman ayat 20, yang mana bahwa seseorang yang mengenal Tuhannya, maka ia wajib mengenal akan dirinya karena identitas diri merupakan intiasari sebuah kepribadian sehingga mengenal diri itu sangat penting. Dalam penelitian ini ditemukan bahwa self identity status sangat berpengaruh terhadap keterbukaan diri yaitu bagaimana mereka mengenalkan dirinya yang berstatus sebagai santri serta mengeksplorasi dan berkomitmen untuk mencari berbagai pengetahuan dan informasi yang berhubungan dengan status dirinya sebagai santri baik untuk pribadinya maupun untuk lingkungan sekitar.

Islam mengajarkan manusia untuk berbangsa-bangsa dan bersuku-suku guna menjalin tali hubungan antar manusia. Sebagaimana dijelaskan dalam surah Alhujurat ayat 13, bahwasanya manusia harus saling mengenal satu sama lain. Kandungan ayat tersebut dapat memberi kita sebuah pemahaman bahwa dorongan untuk selalu terhubung dan mengikatkan diri dalam sebuah hubungan dengan orang lain, merupakan sesuatu yang melekat dalam penciptaan manusia itu sendiri sebagai bekal menjalani kehidupannya. Dalam penelitian ini bahwa affliation motive berperan terhadap self disclosure santri, yang berarti santri selalu merasa senang ketika bersama orang lain, selalu banyak mendapatkan informasi dari orang lain sehingga santri lebih terbuka saat bersama dengan orang lain. Pengungkapan diri merupakan tindakan seseorang dalam memberikan informasi yang bersifat pribadi pada orang lain secara sukarela dan disengaja untuk maksud memberi informasi tentang dirinya. Hal ini tergambar dalam Alquran surah Alma'arij ayat 19-21, bahwa manusia diciptakan untuk berkeluh kesah apabila ia ditimpa kesusahan artinya manusia boleh mengungkapkan keluh kesah dirinya. Namun, tidak harus berlebihan dalam pengungkapannya sehingga dalam penelitian ini santri cenderung rendah dalam hal keterbukaan diri.

Penelitian ini telah membuktikan bahwa self identity status dan affiliation motive berperan bagi self disclosure pada santri remaja. Namun demikian sumbangan peran yang diberikan hanya sebesar $12.6 \%$. Hal ini menunjukkan bahwa keberadaan self identity status dan affiliation motive hanyalah bagian kecil dari sejumlah faktor yang dapat memprediksi self disclosure 
mereka. Studi Park dkk. (2011) tidak menemukan hubungan langsung antara kebutuhan afiliasi dan keterbukaan diri. Sebaliknya, kebutuhan afiliasi lebih berkaitan dengan motivasi untuk inisiasi dan pemeliharaan hubungan, yang pada gilirannya memengaruhi pengungkapan diri dan keintiman. Penelitian lain juga menunjukkan bahwa motif yang paling umum untuk menggunakan Facebook adalah pemeliharaan hubungan (relationship maintenance), mengisi waktu (passing time), dan hiburan (entertainment) (Special \& Li-Barber, 2012). Sedangkan menurut Hollenbaugh dan Ferris (2014) beberapa faktor yang berkontribusi pada dimensi pengungkapan diri yaitu big five personality, self-esteem, social cohesion, dan motif. Studi-studi tersebut dapat memperkuat alasan rendahnya peran affiliation motive bagi self disclosure dalam penelitian ini, karena dimungkinkan banyaknya variabel yang mengantarai keduanya.

Beberapa keterbatasan dalam penelitian ini diantaranya: pertama, jumlah sampel yang kurang banyak, memungkinkan terbatasnya generalisasi hasil penelitian. Kedua, tidak dilakukannya penggalian data-data yang lebih spesifik, misalnya terkait jumlah media sosial yang dimiliki, jenis media sosial yang sering digunakan, konten status yang sering diupload atau diamati dari orang lain, jenis kelamin, status tempat tinggal di asrama atau non asrama dan lain sebagainya yang diduga dapat turut berpengaruh terhadap ketiga variabel yang diteliti, khususnya self disclosure. Sejumlah data tersebut seharusnya diteliti didasarkan pada beberapa temuan hasil penelitian. Pengungkapan diri tidak secara konsisten ditemukan lebih besar dalam konteks online. Faktor-faktor seperti hubungan antar komunikator, cara atau gaya komunikasi tertentu, dan konteks interaksi tampaknya memoderasi tingkat pengungkapan diri tersebut (Nguyen dkk., 2012). Dalam penelitian lain ditemukan bahwa pria dan wanita berbeda dalam tingkat pengungkapan diri serta jenis informasi yang disajikan pada halaman facebook mereka (Special \& Li-Barber, 2012). Jumlah jejaring sosial yang dimiliki remaja juga berhubungan dengan intensitas komunikasi melalui jejaring sosial (Widiantari \& Herdiyanto, 2013).

\section{Simpulan}

Dapat disimpulkan bahwa self identity status dan affiliation motive, baik sendiri ataupun bersama-sama dapat berperan sebagai faktor-faktor yang mendasari keterbukaan diri santri remaja di media sosial. Penelitian ini juga menemukan bahwa remaja yang secara khusus menyandang predikat sebagai santri, sebagaimana remaja pada umumnya yang sedang berada pada tahap pencarian identitas diri, menunjukkan kategori yang beragam dalam hal self identity status dengan jumlah terbanyak berada pada achievement yaitu eksplorasi tinggi yang disertai komitmen tinggi, serta kategori diffusion yaitu eksplorasi dan komitmen yang sama-sama rendah.

\section{Daftar Pustaka}

Andrews, J. L., Foulkes, L., \& Blakemore, S. (2020). Peer influence in adolescence: Public-health implications for covid-19. Science \& Society, 24(8), 585-587. https://doi.org/10.1016/j.tics.2020.05.0 01

Christofides, E., Muise, A., \& Desmarais, S. (2009). Information disclosure and control on facebook: Are they two sides of the same coin or two different processes. Journal of Cyberpsychology \& Behavior, 12(3), 341-345. http://dx.doi.org/10.1089/cpb.2008.022 6

Devito, J. A. (2011). Komunikasi antar manusia. Karisma Publishing Group.

Fauzia, A. Z., Maslihah, S., \& Ihsan, H. (2019). Pengaruh tipe kepribadian 
terhadap self-disclosure pada dewasa awal pengguna media sosial instagram di kota Bandung. Jurnal Psikologi Sains dan Profesi (Journal Psychology of Science and Profession), 3(3), 151160.

https://doi.org/10.24198/jpsp.v3i3.234 34

Ghozali, I. (2011). Aplikasi analisis multivariate dengan program IBM SPSS 19 (Edisi 5). Universitas Diponegoro.

Hill, C. (1987). Affiliation motivation: People who need people but in different ways. Journal of Personality and Social Psychology, 52(5), 100818. https://doi.org/10.1037/00223514.52.5.1008

Hollenbaugh, E. E., \& Ferris, A. L. (2014). Facebook self-disclosure: Examining the role of traits, social cohesion, and motives. Computers in Human Behavior, 30, 50-58. https://doi.org/10.1016/j.chb.2013.07.0 55

Kim, J., \& Dindia, K. (2011). Online selfdisclosure: A review of research. Dalam K. B. Wright \& L. M. Webb (Eds.), Computer-mediated communication in personal relationships (hal. 156-180). Peter Lang Publishing.

Knop, K., Öncü, J. S., Penzel, J., Abele, T. S., Brunner, T., Vorderer, P., \& Wessler, H. (2016). Offline time is quality time: Comparing within-group self-disclosure in mobile messaging applications and face-to-face interactions. Computers in Human Behavior, 55(Part B), 1076-1084. https://doi.org/10.1016/j.chb.2015.11.0 04

Laila, Y. N. (2015). Korelasi antara kebutuhan afiliasi dan keterbukaan diri dengan intensitas menggunakan jejaring sosial pada siswa kelas viii SMP negeri 15 Yogyakarta (Skripsi tidak diterbitkan). Universitas Negeri Yogyakarta, Fakultas Ilmu Pendidikan.
Lee, F., \& Andriani, I. (2012). Privasi dan keterbukaan diri. Jurnal Psikologi, $4(1)$.

https://ejournal.gunadarma.ac.id/index. php/psiko/article/view/376

Mahendra, D. (2014). Media jejaring sosial dalam dimensi self disclosure (Studi deskriptif kualitatif penggunaan twitter pada suporter PSS Sleman "brigata curva sud”) (Skripsi tidak diterbitkan). UIN Sunan Kalijaga Yogyakarta, Fakultas Ilmu Sosial dan Humaniora, Program Studi Ilmu Komunikasi.

Mar'ati, R. (2014). Pesantren sebagai basis pendidikan karakter: Tinjauan psikologis. Al-Murabbi: Jurnal Studi Kependidikan dan Keislaman, 1(1), 115.

http://ejournal.kopertais4.or.id/matara man/index.php/murabbi/article/view/1 62

Marcia, J. E., Waterman, A. S., Matteson, D. R., Archer, S. L., \& Orlofsky, J. L. (1993). Ego identity: A handbook for psychological research. Springer-Verlag.

Masturah, A. N. (2013). Pengungkapan diri antara remaja Jawa dan Madura. Cognicia, l(1). https://doi.org/10.22219/COGNICIA.V ol1.No1.\%25p

Melumad, S., \& Meyer, R. (2020). Full disclosure: How smartphones enhance consumer self-disclosure. Journal of Marketing, 84(3), 2845. https://doi.org/10.1177/002224292 0912732

Minanti, R. D. (2016). Hubungan kebutuhan afiliasi dengan pengungkapan diri pada pengguna media sosial (Skripsi tidak diterbitkan). Universitas Muhammadiyah Malang, Fakultas Psikologi.

Nashori, F. (2016). Kekuatan karakter santri. Millah: Jurnal Studi Agama, 11(1). 203-219. https://doi.org/10.20885/millah.vol11.i ss1.art10 
Nesi, J., Choukas-Bradley, S., \& Prinstein, M. J. (2018). Transformation of adolescent peer relations in the social media context: Part 2-Application to peer group processes and future directions for research. Clin Child Fam Psychol Rev, 21(3), 295-319. https://doi.org/10.1007/s10567-0180262-9

Nguyen, M., Bin, Y. S., \& Campbell, A. (2012). Comparing online and offline self-disclosure: A systematic review. Cyberpsychology, Behavior, and Social Networking. Cyberpsychology, Behavior, and Social Networking, 15(2) 103-111. https://doi.org/10.1089/cyber.2011.027 7

Paluckaitè, U., \& Žardeckaitè-Matulaitienè, K. (2012, January). Gender differences in self-disclosure for the unknown person on the internet communication [Conference] Advanced Research in Scientific Areas 2012 (ARSA). https://doi.org/10.13140/2.1.5036.0328

Park, N., Jin, B., \& Jin, S. (2011). Effects of self-disclosure on relational intimacy in facebook. Computers in Human Behavior, 27(5). 1974-1983. https://doi.org/10.1016/j.chb.2011.05.0 04

Pohan, F. A., \& Dalimunthe' H. A. (2017). Hubungan intimate friendship dengan self-disclosure pada mahasiswa psikologi pengguna media sosial facebook. Jurnal Diversita, 3(2), 1524.

https://doi.org/10.31289/diversita.v3i2. 1256

Pribadi, A. S., Pratiwi, M. M. S., \& Brotowidagdo, R. (2011). Motif afiliasi pengguna aktif facebook. Jurnal Psikologi Proyeksi, 6(2), 5057. https://doi.org/10.30659/jp.6.2.5057

Ratnasari, E. D. (2015). Hubungan antara keterbukaan diri dan kebutuhan afiliasi dengan intensitas penggunaan situs jejaring sosial pada remaja di SMA laboratorium Universitas Negeri Malang (Skripsi tidak diterbitkan). Universitas Negeri Malang, Fakultas Pendidikan Psikologi, Jurusan Psikologi.

Rinjani, H., \& Firmanto, A. (2013). Kebutuhan afiliasi dengan intensitas mengakses facebook pada remaja. Jurnal Ilmiah Psikologi Terapan, 1(1), 76-85.

https://doi.org/10.22219/jipt.v1i1.1359

Rizal, M. N., \& Rizal, G. L. (2021). Hubungan antara intimate friendship dengan self-disclosure pada mahasiswa pengguna whatsapp. Proyeksi, 16(1), 15-24. http://dx.doi.org/10.30659/jp.15.2.192201

Special, W. P, \& Li-Barber, K. T. (2012). Self-disclosure and student satisfaction with Facebook. Computers in Human Behavior, 28(2). 624-630. https://doi.org/10.1016/j.chb.2011.11.0 08

Toyyebah, $\quad$ Z. (2017). Pengaruh pengungkapan diri di media sosial terhadap perkembangan identitas diri siswa SMAN 2 Pamekasan (Skripsi tidak diterbitkan). Universitas Islam Negeri Maulana Malik Ibrahim.

Walrave, M., Vanwesenbeeck, I., \& Heirman, W. (2012). Connecting and protecting? Comparing predictors of self-disclosure and privacy settings use between adolescents and adults. Cyberpsychology: Journal of Psychosocial Research on Cyberspace, 6(1),

Article

3. https://doi.org/10.5817/CP2012-1-3

Widiantari, K. S., \& Herdiyanto, Y. K. (2013). Perbedaan intensitas komunikasi melalui jejaring sosial antara tipe kepribadian ekstrovert dan introvert pada remaja. Jurnal Psikologi Udayana, 1(1), 106-115. https://doi.org/10.24843/JPU.2013.v01 i01.p11 